\title{
Effects of Trialkyltin Chlorides on Isolated Rat Hepatocytes
}

\author{
Jiro YAMADA \\ Laboratory of Food Science, Faculty of Education, Yamaguchi University, \\ 1677-1 Yoshida, Yamaguchi 753, Japan \\ Received March 4, 1991
}

\begin{abstract}
Effects of trialkyltin chlorides on isolated rat hepatocytes were examined. Incubation of isolated hepatocytes with trialkyltin chloride at concentrations of $1-100 \mu \mathrm{g} / \mathrm{ml}$ for a 2 -hr period resulted in a rapid decrease of cell viability. While both triethyl- and tributyltin chloride intensely inhibited oxygen uptake in isolated hepatocytes, tributyltin chloride proved to be much more toxic than triethyltin chloride. Triethyltin chloride strongly inhibited mitochondrial respiration at the low concentrations. Cells treated with tributyltin chloride leaked large amounts of magnesium, protein, and 260-nm-absorbing materials. Cells treated with triethyltin chloride also showed same leakages, but to a lesser degree. Electron microscopic observation showed that the surfaces and intracellular structures of isolated hepatocytes were badly damaged by tributyltin chloride.
\end{abstract}

Various tin compounds have long been used in a wide variety of fields. ${ }^{1-3}$ Besides the metallic tin used to make tin cans, dialkyl-, trialkyl-, and triphenyltin compounds have been used as stabilizers for plastics, fungicides, microbicides, and sterilizers for insects. At present, however, it has become a serious concern that sea water and seafoods may be contaminated by organotin compounds used in antiseptic ship paints.

The potential value of organotin compounds as fungicides has been pointed out by Van Der Kerk and Luijten. ${ }^{4-6)}$ My co-workers and I previously reported the inhibitory effects of trialkyltin compounds on the synthesis of protein, DNA, RNA, and active transport systems in Escherichia coli. ${ }^{7-12)}$ Aldridge and Cremer ${ }^{13-15)}$ have showed that trialkyltin chlorides inhibit mitochondrial oxidative phosphorylation in rat brain and liver cells in vitro. Since these reports were published, trialkyltin compounds have been used mainly as reagents for examining the mitochondrial energy yielding system.

However, there have been no reports of any studies of the effects of organotin compounds on whole isolated hepatocytes. In this paper, therefore, the effects of trialkyltin chlorides on viability, oxygen uptake, and leakage of cell constituents in isolated hepatocytes were examined. Furthermore, cells treated with these compounds were observed under scanning electron microscope and transmission electron microscope.

\section{Materials and Methods}

Chemicals. Trimethyl- and tributyltin chloride were obtained from Tokyo Chemical Industries Co. (Tokyo). Triethytin chloride was synthesized by the method of Van Der Kerk et al. ${ }^{5}$ Collagenase (Type 1) and trypsin inhibitor (Type 2-S) were obtained from Sigma Chemical Co. (U.S.A.) and nembutal-Na from Abbott Laboratories Co. (U.S.A.).

Preparation of isolated rat hepatocytes. Hepatocyte suspensions were prepared by a slight modification of the method of Seglen. ${ }^{16)}$ Male Sprague-Dawley rats (150$200 \mathrm{~g}$ ) were used in all experiments. They were maintained under a 12-hr light-dark cycle and fed commercial chow. Under nembutal-Na anesthesia, the abdomen and chest of each rat were opened, and the liver was perfused via the portal vein with $100 \mathrm{ml}$ of calcium- and magnesium-free Hanks' solution containing $0.5 \mathrm{~mm}$ ethylene-glycol-bis $(\beta$ amino-ethylether)- $N, N^{\prime}$-tetracetic acid (pH 7.2) for $20 \mathrm{~min}$. The liver was continuously perfused with $70 \mathrm{ml}$ of enzyme solution containing $0.05 \%$ collagenase, $0.005 \%$ trypsin inhibitor, and $10 \mathrm{~mm} N$-2-hydroxyethyl-piperazine- $N^{\prime}-2$ ethansulfonic acid (HEPES, pH 7.5). After that, each liver was disconnected by gentle pipetting in $30 \mathrm{ml}$ of enzyme solution. The cells were separated by centrifugation at $50 \times g$ for $2 \mathrm{~min}$. Isolated cells were washed, and damaged 
and nonparenchymal cells were removed by repeated centrifugation at $50 \times g$ for $2 \mathrm{~min}$ at $0-4^{\circ} \mathrm{C}$. The cell pellet was resuspended after each wash in incubation medium to produce the final cell suspension. Cells were counted by an EKDS hemacytometer and viability was measured by trypan blue dye exclusion. Cells were isolated with viability at about $80-90 \%$.

Measurement of oxygen uptake. Oxygen uptake was measured in a 4-ml reaction chamber with an oxygen electrode (YSI model 53 ) at $37^{\circ} \mathrm{C}$. The reaction was started by adding $1.0 \times 10^{5}$ cells to a chamber filled with Hanks' solution. One minute later, trialkyltin chlorides were added to the reaction mixture at final concentrations of $1-500 \mu \mathrm{g} / \mathrm{ml}$.

Preparation of liver mitochondria. Rat liver mitochondria were purified by a slight modification of the method of Noda $e t a l .{ }^{17)}$ The isolated hepatocytes were homogenized with nine volumes of buffer containing $0.21 \mathrm{~m}$ mannitol, $1 \mathrm{~mm}$ Tris- $\mathrm{HCl}$ ( $\mathrm{pH} 7.2$ ) $0.07 \mathrm{M}$ sucrose, and $0.1 \mathrm{~mm}$ ethylene-glycol-bis( $\beta$-amino-ethylether)- $N, N^{\prime}$-tetracetic acid. The homogenate was centrifuged at $9000 \times g$ for $10 \mathrm{~min}$. The resultant precipitate was suspended in mannitol buffer and centrifuged again under the same conditions. The precipitate was used as the mitochondria fraction. Mitochondrial protein was measured by the method of Lowry et al. ${ }^{18)}$

Measurement of leakage of cell constituents. $1.25 \times 10^{5}$ cells were suspended in $5 \mathrm{ml}$ of fresh medium and the triakyltin chloride was added to cell suspensions at final concentrations of $1-100 \mu \mathrm{g} / \mathrm{ml}$. Then they were incubated at $37^{\circ} \mathrm{C}$ for $60 \mathrm{~min}$. A supernatant was obtained by centrifugation at $50 \times \mathrm{g}$ for $5 \mathrm{~min}$. The amount of magnesium in the supernatant was measured using a Hitachi model 207 atomic absorption spectrophotometer and the amount of protein was measured by the method of Lowry et al. ${ }^{18)}$

Electron microscopic observation. Hepatocytes treated with tributyltin chloride were observed under a scanning electron microscope (SEM; JEOL, JMS-T100) and under a transmission electron microscope (TEM; JEOL, JEM-1200EX). After treatment with $10 \mu \mathrm{g} / \mathrm{ml}$ of tributyltin chloride for $60 \mathrm{~min}$, the cells were collected by centrifugation at $50 \times g$ for $5 \mathrm{~min}$, washed thrice with Hanks' solution and fixed with $2 \%$ glutaraldehyde and $1 \%$ osmium tetroxide. Specimens for SEM observation were dehydrated with ethyl alcohol, dried by critical point drying (HCP-2) with carbon dioxide, and coated with gold by an ion sputter (JEC-1100). Specimens for TEM observation were positively stained with $1 \%$ uranyl acetate and $2 \%$ lead nitrate. Electron accelerators for SEM and TEM were operated at $20 \mathrm{kV}$ and $80 \mathrm{kV}$, respectively.

\section{Results and Discussion}

Effects on the viability of isolated hepatocytes

A 5-ml hepatocyte suspension containing $2.5 \times 10^{4}$ cells $/ \mathrm{ml}$ was incubated in Hanks'
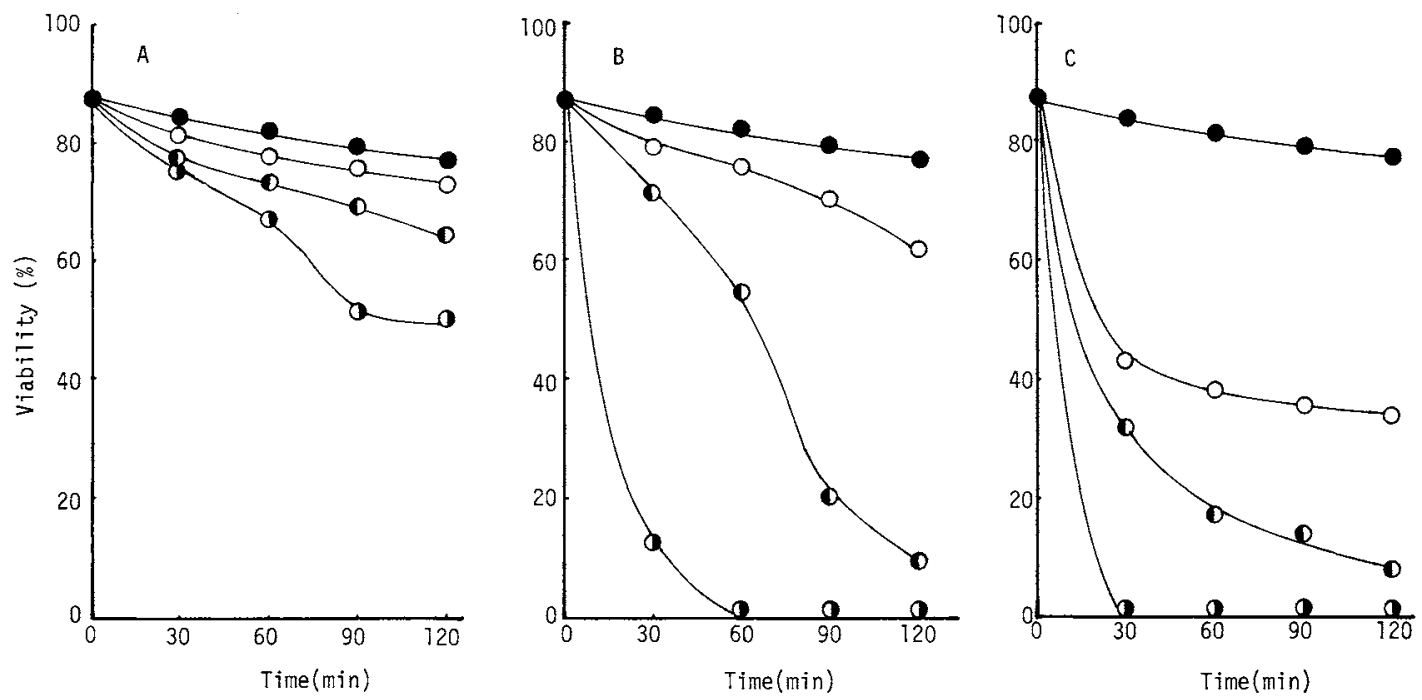

Fig. 1. Effects of Trialkyltin Chlorides on Viability of Isolated Rat Hepatocytes at $37^{\circ} \mathrm{C}$.

A $5-\mathrm{ml}$ suspension of hepatocytes containing $2.5 \times 10^{4} \mathrm{cells} / \mathrm{ml}$ was incubated at $37^{\circ} \mathrm{C}$ for $2 \mathrm{hr}$. Trialkyltin chlorides were added to final concentrations of $1-100 \mu \mathrm{g} / \mathrm{ml}$.

A, trimethyltin chloride; $\mathrm{B}$, triethyltin chloride; $\mathrm{C}$, tributyltin chloride; $10 ; 0,100 \mu \mathrm{g} / \mathrm{ml}$. 
solution at $37^{\circ} \mathrm{C}$ for $2 \mathrm{hr}$. Trialkyltin chloride was added at final concentrations of $1-100 \mu \mathrm{g} /$ $\mathrm{ml}$. Five-microliter samples of the suspension were taken at indicated intervals for measurement of viability. As shown in Fig. 1, butyltin chloride was the most toxic of all the tin compounds used; causing a rapid decrease in the viability of tributyltin chloride-treated hepatocytes. After $30 \mathrm{~min}$, no viable cells could be found at the concentration of $100 \mu \mathrm{g} / \mathrm{ml}$. The toxicity of trialkyltin compounds on isolated hepatocytes increased with an increase in the carbon number of the alkyl chains. Trialkyltin compounds have similarly been found to have increasingly strong antimicrobial action as the carbon number of the alkyl chains increases. ${ }^{19)}$

Furthermore, trialkyltin compounds have a strikingly increased rate of toxicity at higher temperatures. While fifty percent of the isolated hepatocytes survived beyond $2 \mathrm{hr}$ even at the maximum concentration $(100 \mu \mathrm{g} / \mathrm{ml})$ of tributyltin chloride when incubated at $0^{\circ} \mathrm{C}$, no viable cells were found after $30 \mathrm{~min}$ in the same solution at $37^{\circ} \mathrm{C}$.

\section{Effects on oxygen uptake}

Trialkyltin chlorides were also shown to inhibit oxygen uptake in the isolated hepatocytes. Triethyltin chloride showed very similar levels of inhibition with tributyltin chloride, a slightly stronger inhibitor, completely halting oxygen uptake after about $10 \mathrm{~min}$ at the concentration of $100 \mu \mathrm{g} / \mathrm{ml}$. The fact that tributyltin chloride is only a slightly stronger oxygen uptake inhibitor (Fig. 2), but a significantly stronger toxic agent (Fig. 1) seems contradictory. This discrepancy suggests that tributyltin chloride may have additional inhibitory effects on isolated hepatocytes.

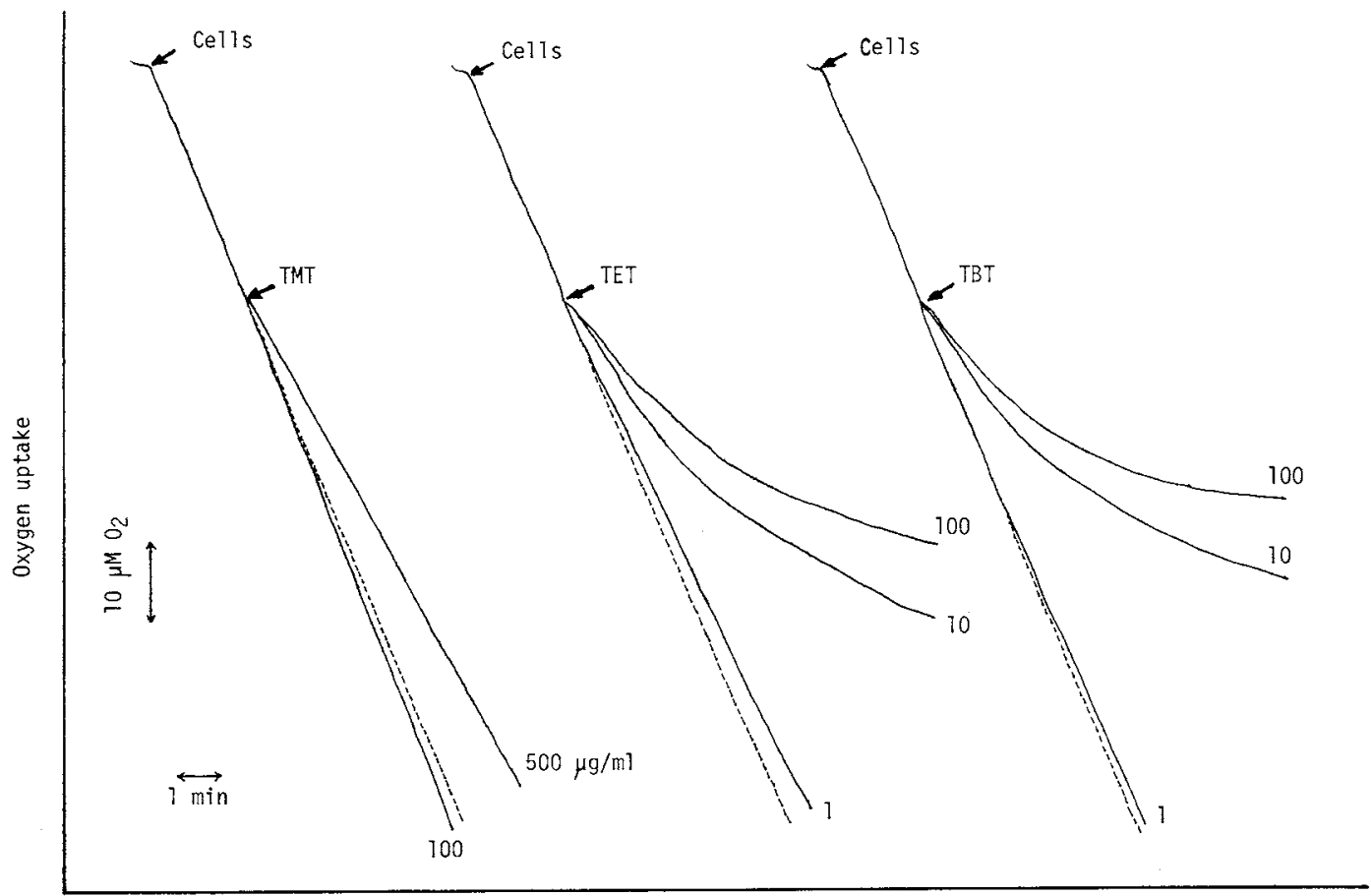

Fig. 2. Effects of Trialkyltin Chlorides on Oxygen Uptake in Isolated Rat Hepatocytes.

Measurements of oxygen uptake were done in a 4-ml reaction chamber with an oxygen electrode at $37^{\circ} \mathrm{C}$. The reaction was started by adding $1.0 \times 10^{5}$ cells to a chamber filled with Hanks' solution. Trialkyltin chlorides were added to the reaction mixtures at $1-500 \mu \mathrm{g} / \mathrm{ml}$.

TMT, trimethyltin chloride; TET, triethyltin chloride; TBT, tributyltin chloride. The notes of these abbreviations are the same as in Fig. 4. 


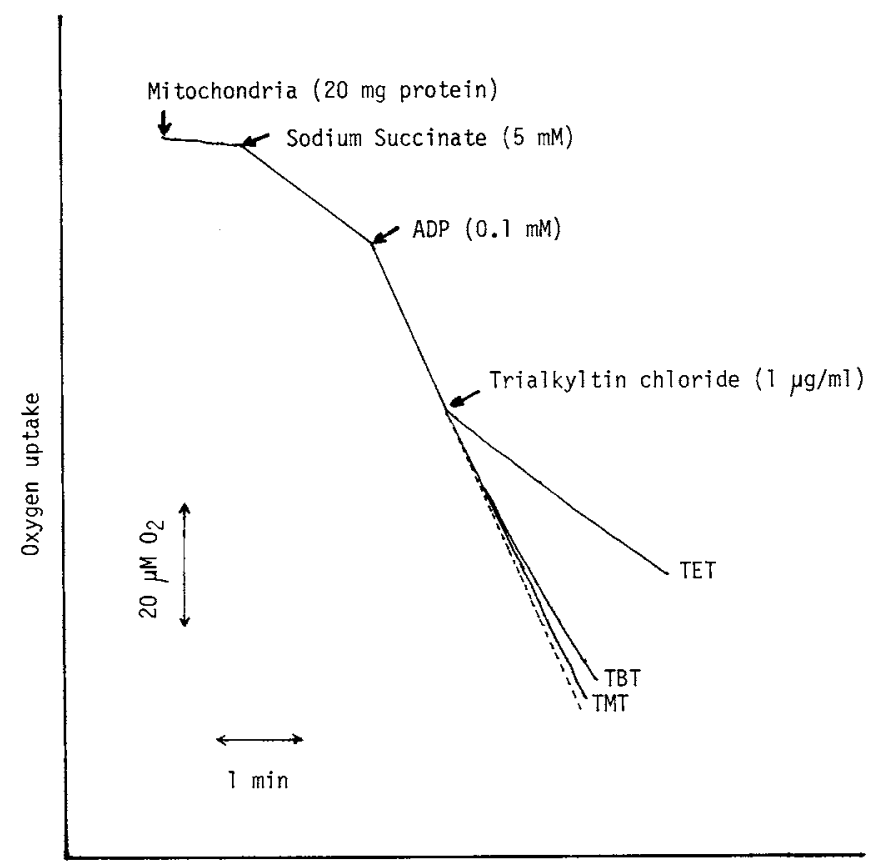

Fig. 3. Effects of Trialkyltin Chlorides on Oxygen Uptake in Rat Liver Mitochondria.

Furthermore, the effects of these compounds on oxygen uptake in mitochondria were also examined. The assay solution contained $0.01 \mathrm{M}$ sodium phosphate $(\mathrm{pH} 7.4), 0.25 \mathrm{M}$ sucrose, $0.01 \mathrm{M}$ potassium chloride, and $2.5 \mathrm{~mm}$ ethylene-glycol-bis( $\beta$-aminoethylether $)-N, N$-tetracetic acid. The reaction was started by adding $20 \mathrm{mg}$ of mitochondrial protein and $5 \mathrm{~mm}$ sodium succinate. Trialkyltin chlorides and ADP (at a final concentration of $0.1 \mathrm{~mm}$ ) were added to the reaction mixture at set intervals. As shown in Fig. 3, mitochondrial respiration was inhibited most intensely by triethyltin chloride. This compound completely inhibited the ADP-stimulated rate of oxygen uptake (state 3 respiration), in other words, the reactions of oxidative phosphorylation. At this concentration, state 2 and 4 respirations were not inhibited by triethyltin chloride. Aldridge and Cremer ${ }^{15)}$ previously reported that the lower trialkyltin compounds were extremly strong inhibitors of oxidative phosphorylation in isolated liver mitochondria of rats. The level of toxicity varied with the length of the alkyl chain; ethyltin compound

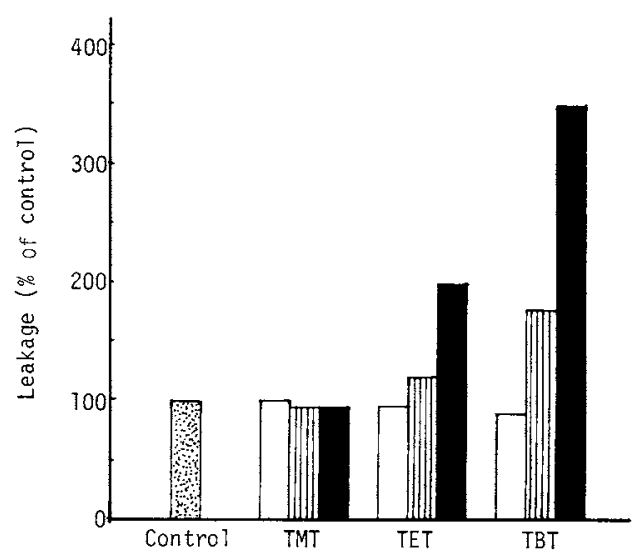

Fig. 4. Leakage of Magnesium from Isolated Hepatocytes Treated with Trialkyltin Chlorides.

Leakages were expressed by the percentage of leakage compared to non-treated cells (control). control; $\square, 1 ; \equiv, 10 ; \square, 100 \mu \mathrm{g} / \mathrm{ml}$.

was found to be the strongest inhibitor, while methyl and butyltin compounds required concentrations 50 times and 10 times stronger, respectively, to show effects comparable to the effect of the ethyltin compound. 
Leakage of cell constituents from isolated hepatocytes

The addition of trialkyltin chloride to cell suspensions of microorganisms has been shown to result in a rapid leakage of some constituents

from cells, and this leakage was an important mechanism in its antimicrobial action. ${ }^{8)}$ In this experiment, therefore, leakages of constituents from trialkyltin chloride-treated hepatocytes were examined.
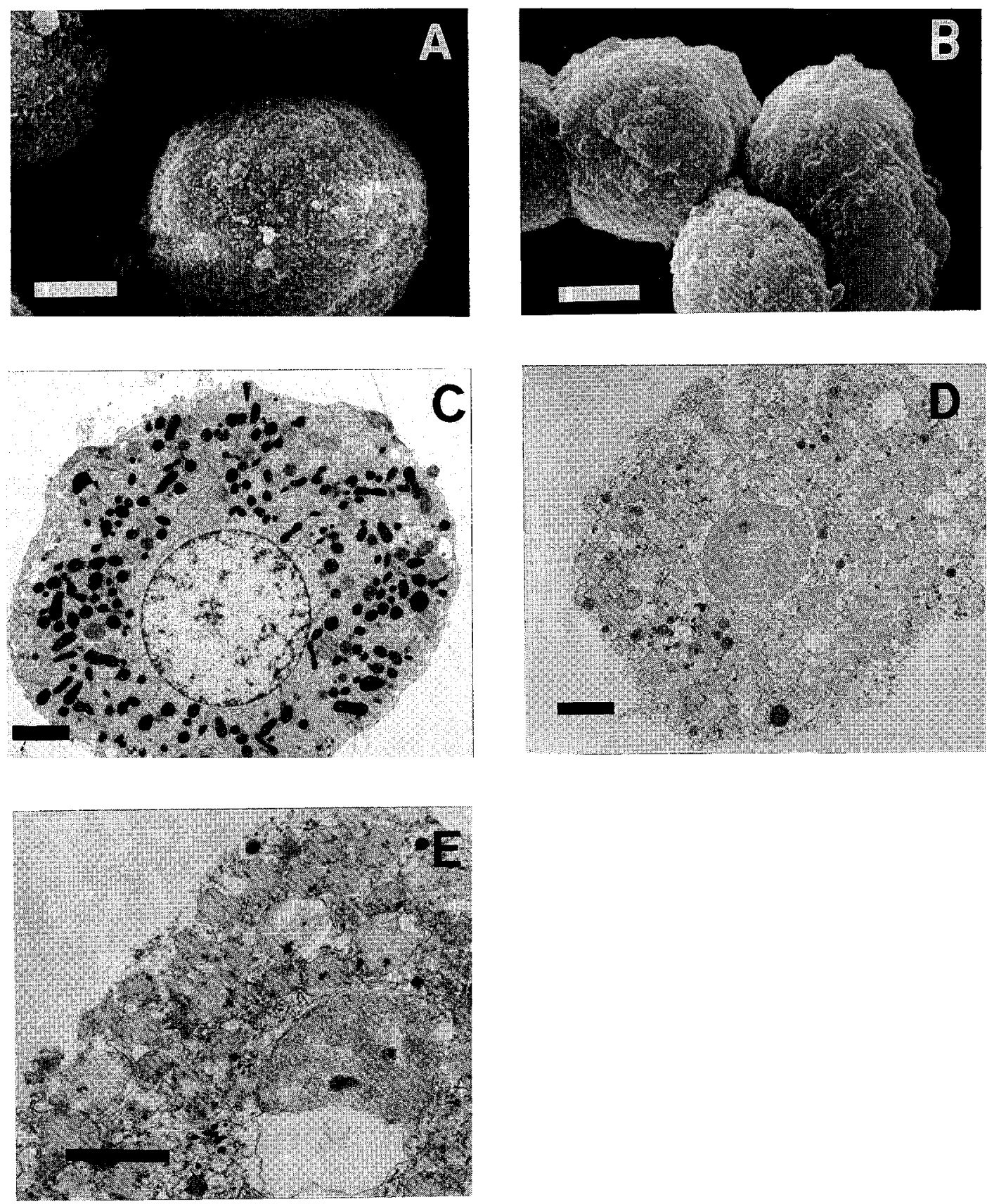

Fig. 5. Electron Micrographs of Isolated Rat Hepatocytes Treated with Tributyltin Chloride.

$\mathrm{A}$ and $\mathrm{C}$, no addition (control); B, D and $\mathrm{E}, 10 \mu \mathrm{g} / \mathrm{ml}$ tributyltin chloride. The black and white bars represent $2 \mu \mathrm{m}$ and $5 \mu \mathrm{m}$, respectively. 
Figure 4 shows the leakages of magnesium. As compared with non-treated cells, tributyltin chloride-treated cells released two to four times as much magnesium depending on the concentration of the tin compound. Protein and 260-nm-absorbing materials also leaked in large quantities into the supernatant.

Large amounts of magnesium and protein exist in the cell membrane and are important in membrane structure and function. ${ }^{20}$ The above results suggest that trialkyltin chlorides, especially tributyltin chloride, may adversely affect cell membranes and damage membrane structures in isolated hepatocytes. In the next experiment, therefore, tributyltin chloridetreated cells were observed under an electron microscope.

\section{Electron microscopic observation}

Electron micrographs of isolated hepatocytes treaed with tributyltin chloride are shown in Fig. 5. SEM of the non-treated hepatocytes demonstrated regular surfaces with grain-like protrusions (Fig. 5A). Conversely, in many cells treated with tributyltin chloride, those surfaces were greatly disrupted. Tributyltin chloride significantly damaged membrane structures and distended the shapes of cells from globular to oval with ragged surfaces (Fig. $5 \mathrm{~B})$.

TEM of the control hepatocytes demonstrated regular intracellular structures; nucleus in the center, granular endoplasmic reticulum and mitochondria with crests scattered throughout the cytoplasm (Fig. 5C). In many cells treated with tributyltin chloride, intracellular structures were badly damaged; cell membranes were torn away in places, and many organelles were intensely deformed. Many mitochondria were swollen (Fig. 5D) and in many cases, their crests disappeared (Fig. 5E). In spite of this damage to the mitochondria, oxygen uptake was scarcely inhibited (Fig. 3). One reason for this discrepancy may be the large difference in the concentration of tributyltin chloride used and the difference in incubation time between Figs. 3 and 5 .

In previous studies using phospholipids ${ }^{9)}$ and liposome models, ${ }^{7)}$ my co-workers and I have shown that trialkyltin compounds may have a damaging effect on the phospholipids in cell membranes. The results shown in Figs. 4 and 5 suggest that similar interactions may occur in whole, isolated hepatocytes.

While the results of this paper were obtained using isolated hepatocytes which were different from normal liver cells, these findings suggest that trialkyltin compounds may have additional toxic effects beyond the inhibition of oxidative phosphorylation in animal cells. The relatively equal inhibition of oxygen uptake by tributyltin chloride and triethyltin chloride (Fig. 2) contrasted with the significantly higher toxicity rate of tributyltin in Fig. 1 suggests that something beyond oxygen uptake inhibition is killing the cells. Leakage of magnesium and protein may cause a breakup of the cell membranes affected by treatment with tributyltin chloride, and also suggests organelles may be affected. More research needs to be done on the effects of these compounds on animal cells to identify their danger to the environment.

Acknowledgments. The author expresses great gratitude to Dr. Kazumi Hoshide of Yamaguchi University and Dr. Makoto Yoshimoto of Kyushu University for their kind help in doing electron microscopic observations, and to Miss Suzanne Schmitt for her advice during the development of the presentation of this research.

\section{References}

1) G. J. M. Van Der Kerk, Ind. Eng. Chem., 58, 29 (1966).

2) E. Eugene, J. Econom. Entromol., 58, 14 (1965).

3) A. Takeda, Shokuhin Eisei Kenkyu, 22, 1103 (1972).

4) G. J. M. Van Der Kerk and J. G. A. Luijten, J. Appl. Chem., 4, 314 (1954).

5) G. J. M. Van Der Kerk and J. G. A. Luijten, J. Appl. Chem., 6, 49 (1954).

6) G. J. M. Van Der Kerk and J. G. A. Luijten, J. Appl. Chem., 6, 56 (1954).

7) J. Yamada, K. Tatsuguchi and T. Watanabe, Agric. Biol. Chem., 42, 2867 (1978).

8) J. Yamada, K. Tatsuguchi and T. Watanabe, Agric. Biol. Chem., 43, 125 (1979).

9) J. Yamada, K. Oishi, K. Tatsuguchi and T. Watanabe, Agric. Biol. Chem., 43, 1015 (1979).

10) J. Yamada and T. Watanabe, Agric. Biol. Chem., 43, 
1293 (1979)

11) J. Yamada and T. Watanabe, Agric. Biol. Chem., 43, 1681 (1978).

12) J. Yamada, Agric. Biol. Chem., 45, 997 (1981).

13) W. N. Aldridge and J. E. Cremer, Biochem. J., 61, 406 (1955).

14) W. N. Aldridge and J. E. Cremer, Biochem. J., 67, 423 (1957).

15) W. N. Aldridge and J. E. Cremer, Biochem. J., 69, 20) C. McClare, Nature, 216, 766 (1967).

367 (1958).

16) P. O. Seglen, Meinod Cell Biol., 13, 29 (1976).

17) K. Noda, M. Yoshimoto, S. Hatano and $T$. Watanabe, J. Food Hyg. Soc. Jpn., 26, 203 (1985).

8) O. H. Lowry, N. J. Rosebrough, A. L. Farr and R. J. Randall, J. Biol. Chem., 193, 265 (1951).

19) J. Yamada, K. Tatsuguchi and T. Watanabe, Agric. Biol. Chem., 42, 1167 (1978). 